\title{
Recycling Biowaste - Human and Animal Health Problems
}

\author{
By Ann Albihn
}

Section of Environment and Biosecurity, National Veterinary Institute, S-751 89 Uppsala.

\begin{abstract}
Biowaste from the food chain is of potential benefit to use in agriculture. Agriculture in general and organic farming in particular needs alternative plant nutrients. However, the quality concerning hygiene and soil contaminants must be assured. This recycling has to be regulated in a way that harmful effects on soil, vegetation, animals and man are prevented.

The problems with heavy metals and organic contaminants have been focused on. Still, maximum threshold values are continuously discussed to avoid an increase of soil concentrations. The effect on the ecosystems of residues from use of medicines needs further attention. There is also a risk for a spread of antibiotic resistant micro-organisms in the environment and then to animals and man. Infectious diseases may be spread from biowaste and new routes of disease transmission between animals and humans can be created. Zoonotic diseases in this context play a central role. Pathogens recently introduced to a country may be further spread when biowaste is recycled. The very good health status of domestic animals in the Nordic countries may then quickly change.

The quality of biowaste is of enormous importance if biowaste is to gain general acceptance for agricultural use, especially for organic production. A balance needs to be maintained between risk and advantage for its use.
\end{abstract}

Biowaste, agricultural use, health problems, pathogens, zoonoses, epizootic diseases, heavy metals, medical residues.

\section{Introduction}

The collection and utilisation of biowaste (e.g. waste from slaughterhouses, households, restaurants, food and beverage industry and from toilets) is a central component in the development of a sustainable society. The outlet of nitrogen to water and air, the use of petrol and commercial fertilisers and the negative impact on the environment of waste handling can be reduced if increasing amounts of biowaste is to be recycled. For agriculture it may be attractive to use recycled biowaste, mainly as a fertiliser but also for energy and as feedstuff. Farmers, especially organic farmers need alternatives to mineral fertilisers (KRAV 2001). Manure and crop wastes are not enough to com- pensate for meat, milk, vegetables and other products that are taken away from the farm. Sewage sludge and other biowastes have been extensively used in conventional agriculture in all Nordic countries except Iceland, (Petersen \& Petersen, 1998), however, for organic farming sewage sludge is not accepted. But, recycling of biowaste has to be regulated and controlled in such a way that harmful effects on soil, vegetation, animals and man are prevented (Feachem et al. 1983, Inger et al. 1997, Witter et al. 1994).

\section{Heavy metals and organic contaminants}

The problems with heavy metals and organic 
contaminants in agriculture are known since long. There is evidence of serious adverse effects on soil microbial processes of increasing soil metal concentrations (Bååth 1989, Witter et al. 1994). As in other Nordic countries central authorities are regulating the maximum thresholds of heavy metals in sewage sludge. In Sweden 7 metals are controlled; lead, cadmium, copper, chromium, mercury, nickel and zinc (Swedish EPA 1994, Swedish EPA 1998). Even so, maximum thresholds and annual loading rates to ensure that the soil concentrations will not be exceeded are continuously discussed.

For cadmium we may already have passed that threshold (Järup et al. 1998). Calculations show that the accepted loading rates for cadmium will add many new cases of injured kidneys in humans (Drake et al. 1997). For some of these metals the accepted loading rates are believed to allow a rapid accumulation in soil (Wallgren 1999). For many other metals as vanadium, cobalt, wolfram, platinum, uranium and silver there are no regulations. Especially for silver which is toxic for soil micro-organisms, there is a risk for an extremely fast increase in soil (Wallgren 1999).

Brominated flame-retardants are another contaminant that has been focused on. There has been an increase of this substance in sewage sludge over the last years which in October 1999, caused the Federation of Swedish farmers to recommend that sewage sludge should not be used on agricultural land (Eksvärd 1999). To ensure sustainable agriculture it is important to bear in mind that only waste that could be traced back to arable land should be recycled for agricultural purposes.

The Swedish certification body for organic farming (KRAV 2001) has set up regulation for maximal annual loading rates for many metals in fertilisers, soil conditioners, pesticides and all other products which may be applied to soil. Its somewhat surprising that the maximal load-
Table 1. Annually accepted metal loading rates.

\begin{tabular}{lrc}
\hline Metal $(\mathrm{g}) /$ hectar/year & KRAV & SNFS \\
\hline Lead $(\mathrm{Pb})$ & 50 & 25 \\
Cadmium $(\mathrm{Cd})$ & 1 & 0.75 \\
Copper $(\mathrm{Cu})$ & 500 & 300 \\
Chromium $(\mathrm{Cr})$ & 50 & 40 \\
Mercury $(\mathrm{Hg})$ & 1.5 & 1.5 \\
Nickel $(\mathrm{Ni})$ & 50 & 25 \\
Zinc $(\mathrm{Zi})$ & 700 & 600 \\
\hline
\end{tabular}

KRAV: Swedish certification body for organic farming, loading rates apply to fertilisers, soil conditioners, pesticides and all other products applied to soil

SNFS: Regulation from Swedish EPA, loading rates applies to sewage sludge (SNFS 1994:2 and 1998:4)

ing rates for six out of seven metals are higher for organic farming than for sewage sludge (Swedish EPA 1994; Swedish EPA 1998) (table 1).

\section{Residues from medical use}

The human and animal medical consumption results in residues of pharmaceuticals or metabolites thereof in faeces and urine. Antibiotics are most probable the main problem but hormones and anti-parasite drugs have also been focused on (Swedish EPA 1996). During the past decades, micro-organisms have developed resistance to many of the antibiotics commonly used for treatment of infectious diseases (Witte 1998). Bacteria residing in the soil exposed to manure, the phytoshere or the animal gut may encounter selection by antibiotics used for either disease treatment, disease prevention or as growth promoters (Witte 1998, 2000, McManus 2000). By recycling biowaste there is risk for a spread in the environment of such microbial resistance and then back to humans and animals.

Gene transfer occurs readily in almost any environment. It has been shown that gene transfer can occur in soil between different bacteria, by various mechanisms (Cresswell \& Wellinton 
1992, Top et al. 1990, Bale et al. 1988). Even so the antimicrobial resistant bacteria do not survive itself the resistant genes may be picked up by other species of bacteria, more suitable to persist in the present environment (Cresswell \& Wellington 1992). In addition, naked DNA can persist in the environment and possibly be picked up by soil bacteria. Transferable genetic elements carrying resistance genes may also carry other traits of advantage (Bale et al. 1993). Co-transfer of genes encoding resistance to copper, sulphur or mercury together with antimicrobial resistance should be considered. $\mathrm{Fi}$ lali and co-workers (2000) have in a study found micro-organisms highly resistant to cadmium, mercury and antibiotics in sewage water of Casablanca. Mercury and its compounds are distributed widely around the world. The genes encoding for mercury resistance can be located on transposons, plasmids and the bacterial chromosome (Osborn et al. 1997). For example, the widespread transposon $\mathrm{Tn} 21$ and its close relatives (Liebert et al. 1999) carry resistance to mercuric chloride, sulfonamide and streptomycin/spectinomycin. It is important to have in mind that presence of heavy metals can possibly select for antibiotic resistance and vice versa.

Transmission of resistant genes between different species of bacteria is not uncommon. These bacteria may in turn be transmitted between different species of animals or between animal and man (Witte 1998). Therefore the problem with antibiotic resistance that readily crosses boundaries may be compared with the transmission of zoonotic pathogens. Also in the same manner as for pathogens antibiotic resistance may be transported long distances with vector animals. For example, multiresistant Salmonella typhimurium has been detected in the south of Sweden in faecal samples from black-headed gull migrating from south Europe (Palmgren et al. 1997).

\section{Pathogens}

A variety of pathogens can be found in biowaste (Löfgren et al. 1978). The use of biowaste on arable land may facilitate the spread of infectious diseases. Hence, new possible routes of disease transmission between urban and rural areas are created. Pathogenic micro-organisms may have long post-spreading survival time in the environment (Mitscherlich \& Marth 1984). Micro-organisms may also have the ability to multiply and wind, water, harvested food- or feedstuff may spread them (Feachem 1983, Albihn \& Stenström 1999). Vector animals, i.e. insects, birds or mammals may transport pathogens long distances (Bö 1980, Sveum \& Sendstad 1982) and then introduce infections to humans or domestic animals.

Some of these pathogen bacteria cause zoonotic diseases, such as verotoxin producing Eschericia coli O157, Salmonella and Campylobacter and is of relevance for public health. Salmonella is almost always present in conventionally treated wastewater and sewage sludge in Sweden (Danielsson 1975, Sahlström 2001). Zoonotic parasites as Taenia saginata and Cryptosporidium parvum are also of great concern when recycling biowaste (Feachem 1983, Marshall et al. 1997). Some pathogens cause epizootic diseases in livestock and are of enormous importance for animal production. Classical swine fever (CFS) is caused by a very resistant virus, this virus may stay infectious e.g. in food waste and faeces for several months (Van Oirschot \& Terpstra 1989). In Sweden wild boars are a potential reservoir for CFS. A reservoir among wild animals may be impossible to eliminate. Newcastle disease virus that affects birds is another example of an epizootic disease relevant when discussing the handling of biowaste. It is also here a risk for a reservoir building up in the wild population. In organic animal production, particularly pig and poultry, animals should be kept outdoors to a greater ex- 
tent than what is prefered in conventional production (KRAV 2001). Thereby the risk for disease transmission between wild and domestic animals increases.

BSE (bovine spongiform encephalopathy) or "mad cow disease" is the most frightening example of what can happen when insufficiently treated biowaste is recycled. The enormous influence the BSEissue has on the political and economical EU-work can not be over-estimated. The problem has passed the stage only being a question of food and feed safety. At present it is a practical problem how to get rid of animal by-products (entire bodies, parts of animals or products of animal origin). The feed ban for meat and bone meal (MBM) have caused growing quantities of this product stored all around Europe. The possibility to use animal risk waste, including MBM as a fertiliser on arable land is restricted. Based on the BSE issue a new EU-regulation is under preparation (COD 2000/0259) laying down how all animal by-products should be handled. Compared with conventional microorganisms, prions are much more difficult to inactivate by both chemical and physical methods. It is likely that significant levels of infectivity will survive if let out in the natural environment, and there is some evidence to support this (SSC 2001).

In the Nordic countries the very good health status of domestic animals (Hopp 1996) as well as the society's generally high sanitary standards must be maintained. Import regulations for animals and animal products have been relaxed during the last period of time, both within the EU as well as between EU-countries and EU-associated countries. Which infectious diseases that are present in a country may quickly change. There is a risk that pathogens recently introduced into a country will be further spread when biowaste is used on arable land. Every year several new disease agents are found in Sweden (Wierup 1989). Effective systems for disease surveillance and control as well as for maintaining a high level of biosecurity are important.

The biosecurity-related legislation regulating the use of biowaste on land differs between the Nordic countries. In Norway and Denmark this regulation includes most kinds of biowaste, in Sweden however it is entirely lacking. An EUlegislation exists for animal risk waste (90/667/EEC), however, a new and extended version is under preparation (COD 2000/0259). Some ongoing work in EU is of great interest, one draft document on biological treatment of biowaste and one on the treatment and use of sludge. In both these documents the biosecurity point of view has been noticed. For organic farmers the use of source separated human urine as a fertiliser has been discussed and rejected in EU, mainly due to ethical reasons, while composted household waste has been accepted. Compost is however a very diverging waste category and no hygienic treatment is specified. In the year 2001 digested residues from biogas plants were accepted, but the kind of biowastes that are allowed to enter the plant is restricted.

The hygienic standard of biowaste should be based on a treatment of known and controlled efficacy, on a microbiological analysis or preferably a combination of these two methods. A balance needs to be maintained between treatment cost and biosecurity. The risk for disease transmission from biowaste should be related to where and how it is to be used. Also an occasional spread of a specific pathogens from other sources in society must be taken into account. Hygienic treatments of biowaste mostly aim at marked reduction of pathogens (Bendixen 1995). However, for high-risk animal waste the BSE problem has caused a need for sterilisation (90/667/EEC). Swedish biogas plants use $70^{\circ} \mathrm{C}$ in 60 minutes, which gives a marked reduction of indicator organisms and of 
the pathogenic bacteria tested (Bagge 2001). However, bacterial spores, some heat-resistant viruses as parvovirus (Bendixen \& Ammendrup 1992, Bendixen 1995) and prions (SSC 2001) persist such treatment.

\section{Conclusion}

Recirculation of nutrients from urban areas to agricultural land is one of the big challenges of our time. If biowaste is to gain general acceptance as a fertiliser in agriculture both a minimal contamination of noxious elements and the hygienic standard must be assured. For organic farming with more reliance on out-door production and less reliance on medication, these animals may be more vulnerable for disease transmission from sources in the environment than animals in conventional farming. Also organic farming relay more on "home-produced" feed and these farms are also more dependent than other farms on alternative fertilisers, for example biowaste. However, the aim is that the hygienic standard of all biowaste either used as fertiliser or as feed should be assured in such a way that the biowaste could be acceptable to use both for conventional and organic farming.

The adverse effects on arable land of increased heavy metal loading and of organic contaminants are mainly dose-dependent and accumulative. The adverse effects of drug residues and pathogenic micro-organisms however, is more dose-independent and may give an instant effect but also long term effects can not be ruled out.

\section{Acknowledgement}

The author wishes to thank Dr. Catarina Wallén, Mr. Gunnar Lindgren and Prof. Anders Engvall for critical review of the manuscript.

\section{References}

Albihn A, Stenström T-A: Systemanalys VA - Hygienstudie. (Systems analysis of sanitation systems- biosecurity). VA - FORSK rapport 199816, Stockholm, Sweden. 1999.

Bagge E: Personal communication. National Veterinary Institute, Uppsala, Sweden, 2001.

Bale MJ, Bennett PM, Beringer JE and Hinton M: The survival of bacteria exposed to desiccation on surfaces associated with farm buildings. J. App. Bacteriol. 1993, 75, 519-528.

Bale MJ, Fry JC, Day MJ: Transfer and Occurrence of Large Mercury Resistance Plasmids in River Epilithon. Appl. Environ. Microbiol. 1988, 54, 972-978.

Bendixen HJ, Ammendrup S: Safeguards against pathogens in biogas plants. The Danish Veterinary Service, Copenhagen, Denmark, 1992.

Bendixen HJ: Smitstofreduktion i biomasse. Bind II. (Pathogen reduction in biowaste. Part II). The Danish Veterinary Service, Copenhagen, Denmark, 1995.

Bååth E: Effects of heavy metals in soil on microbial processes and populations (a review). Water, air, and soil pollution. BM McCormac. Kluwer Academic. Dordrecht, 1989, 47, 337-377.

Bö G: Salmonellafrekvensen i måker på Grönmo söppelfuleplass i Oslo. (The frequencies of salmonella in seagulls at Grönmo landfill site.) Trondheim, Norway, Viltrapport. 1980, 10, 147154.

Cresswell N, Wellington EMH: (eds). Detection of genetic exchange in the terrestrial environment. Pergamon Press, Oxford, GB, 59-82, 1992.

Danielsson M-L: Salmonella in sewage and sludge; serological profiles of isolates, their removal and/or survival in relation to potential health hazards to man and animals. Acta Vet. Scand., 1977, Suppl. 65. Thesis.

Drake/Hellstrand: The Economics of the Swedish Policy to Reduce Cadmium in Fertilisers. In: Exemption Substances Project, Oct 1997. National Chemicals Inspectorate, Stockholm, Sweden, p.112, 1997.

Eksvärd J: Debatt: Är det möjligt att få förtroende för slam. (Is it possible to get confidence in the sludge?), VAV-nytt. 1999, 5, 38-39.

Feachem RG, Bradley DJ, Garelick H, Duncan Mara $D$ : Sanitation and disease; Health aspects of excreta and wastewater management. World bank studies in Water Supply and Sanitation 3. Pitman Press, Bath, GB. 1983. 
Filali BK, Taoufik J, Zeroual Y, Dzairi FZ, Talbi M, Blaghen M: Waste water bacterial isolates resistant to heavy metals and antibiotics. Curr. Microbiol. 2000, 41, 151-156.

Hорр P: The harmonised salmonella control programmes in Finland, Norway and Sweden. Proc. $10^{\text {th }}$ NKVet Symposium. Effects of International Trade on Animal Health, Public Health and Animal Welfare in the Nordic Countries, Hanasaari, Finland, p. 24, 1996.

Inger $M$, Norin E, Mathisen B: Hygienisering av biologiskt avfall. (Hygien treatment of biowaste.) JTI-rapport Kretslopp och Avfall 1997, 10, Jordbrukstekniska Institutet, Uppsala, Sweden.

Järup L, Berglund M, Elinder CG, Norberg G, Vahter $M$ : Health effects of cadmium exposure - a review of the literature and risk estimate. Scand. J. Work Environ. Health. 1998, 1, 1-53.

KRAV, http://www.krav.se. 2001.

Liebert CA, Hall RM, Summers AO: Transposon Tn21, Flagship of the Floating Genome. Microbiol. Mol. Biol. Rev. 1999, 63, 507-522.

Löfgren I, Tullander V, Hovsenius G: Förekomst och överlevnad av mikroorganismer vid samkomposte-ring av hushållsavfall och slam. (Prescence and persistance of microorganisms when composting household waste together with sludge.) SNV PM 1077, Swedish Environmental Protection Agency, 1978, Stockholm, Sweden.

Marshall MM, Naumovitz D, Ortega Y, Sterling CR: Waterborne protozoan pathogens. Clin. Microbiol. Rev. 1997, 10, 67-85.

McManus PS: Antibiotic use and microbial resistance in plant agriculture. ASM News, 2000, 66, 448-449.

Mitscherlich E, Marth EH: (eds.) Microbial Survival in the Environment. Springer Verlag, Berlin, Germany, 1984.

Osborn AM, Bruce KD, Strike P, Ritchie DA: Distribution, diversity and evolution of the bacterial mercury resistance (mer) operon. FEMS Microbiol. Rev. 1997, 19, 239-262.

Palmgren H, Selin M, Bergström S, Olsen B: Enteropathogenic bacteria in migrating birds arriving in Sweden. Scand. J. Infect. Dis. 1997, 29, 565-568.

Sahlström L: Personal communication. National Veterinary Institute, Uppsala, Sweden, 2001.

SSC (Scientific Steering Committee): Pre-emptive risk assessment should BSE in small ruminants be found under domestic conditions. Opinion, 2001, Feb. 8-9, p.41, European Commission,
Brussels, Belgium, 2001.

Swedish EPA: SNFS 1994: 2, Swedish Environmental Protection Agency, Stockholm, Sweden, 1994.

Swedish EPA: Läkemedel och miljö. (Pharmaceutical and environment.) Report 4660. Swedish Environmental Protection Agency, Stockholm, Sweden, 1996.

Swedish EPA: SNFS 1998: 4, Swedish Environmental Protection Agency, Stockholm, Sweden, 1998.

Sveum P, Sendstad E: Avfallsfyllinger og smittespredning med insekter. (Landfill and insects as disease transmitters.) Söppeldagene, Trondheim, SINTEF, Norway's Technical University, Norway, 1982.

Top E, Mergeay M, Springeal D, Verstraete W: Gene escape model: transfer of heavy metal resistance genes from Escherichia coli to Alcaligenes eutrophus on agar plates and in soil samples. Appl. Environ. Microbiol. 1990, 56, 2471-2479.

Wallgren B: Nominella fördubblingstider för metallhalter i jord vid slamgödsling. (The nominal time for doubling the metal concentrations in soil when using sewage sludge as a fertiliser.) Internal PM. 1999.05.13, Swedish Environmental Protection Agency, Stockholm, Sweden, 1999.

Van Oirschot JT, Terpstra C: Swine fever. In: Virus Infections of Porcines. vol. 2, Ed: M.B. Pensaert, Elsevier, 1989, Amsterdam, The Netherlands, 113-130.

Wierup M: Vad gör vi när nya sjukdommar dyker upp. (What to do when new diseases show up.) SVAvet, 1989, 2, 11-13.

Witte $W$ : Medical consequences of antibiotic use in agriculture. Science, 1998, 279, 996-997.

Witte W: Ecological implications of antibiotic use in animals on different complex microflora: environment. Int. J. Antimicrob. Agents, 2000, 14, 321-325.

Witter E, Giller KE, McGrath SP: Long-term effects of metal contamination on soil microorganisms. Soil Biol. Biochem. 1994, 26, 421-422.

\section{Sammanfattning}

Biologiskt avfall från livsmedelskedjan kan vara av stort värde för lantbruket. Hela jordbruket $i$ allmänhet, men ekologisk produktion i synnerhet behöver alternativa gödselmedel. Dock måste kvalitén säkras avseende hygien och oönskade ämnen.

För ekologisk produktion där djuren vistas mer utom- 
hus och mindre medicinering görs är djuren mer sårbara för smittspridning från källor i miljön än djur som hålls i konventionellt jordbruk. Vidare så bygger ekologisk produktion i större utsträckning på "hemmaproducerat" foder och är mer beroende av alternativa gödselmedel än konventionellt jordbruk, t.ex. biologiskt avfall. Dock är målet att den hygieniska standarden på biologiskt avfall, för gödsling eller utfodring, ska säkras på ett sådant sätt att detta avfall kan accepteras både av konventionellt och ekologiskt lantbruk.

Problemet med tungmetaller och oönskade ämnen har uppmärksammats länge. Dock diskuteras kontinuerligt de maximala gränsvärdena för att undvika att en anrikning sker i jord.

Effekterna på ekosystemen av medicinrester behöver uppmärksammas ytterligare. Här finns också en risk för spridning av antibiotikaresistens i miljön och sedan vidare till djur och människor. Även infektionssjukdomar kan spridas med biologiskt avfall. Nya vägar för smittspridning mellan djur och människa kan skapas. Zoonotiska sjukdomar har här en central roll. Patogener som nyligen introducerats i ett land kan spridas vidare med biologiskt avfall i kretslopp. Det mycket goda hälsoläget för animalieproduktionen i de Nordiska länderna kan då snabbt ändras.

En säkrad kvalitet på det biologiska avfallet är av enorm betydelse för en generell acceptans för användning i jordbruket i synnerhet för ekologisk produktion. En balans måste upprätthållas mellan risken och nyttan med ett kretslopp av biologiskt avfall. 